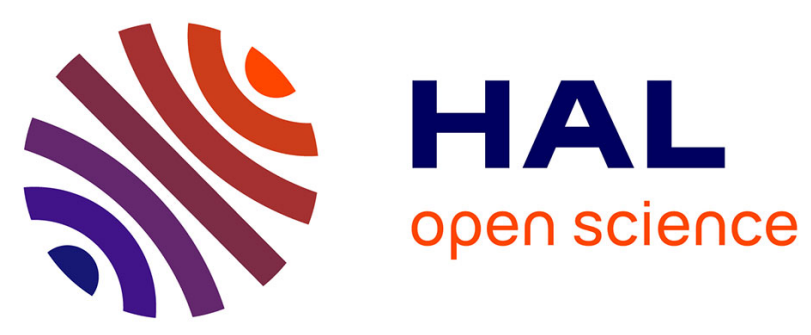

\title{
Evaluation of environmental contamination by toxic trace elements in Kazakhstan based on reviews of available scientific data
}

\author{
Almagul Baubekova, Ainisa Akindykova, Aigerim Mamirova, Camille Dumat, \\ Stefan Jurjanz
}

\section{To cite this version:}

Almagul Baubekova, Ainisa Akindykova, Aigerim Mamirova, Camille Dumat, Stefan Jurjanz. Evaluation of environmental contamination by toxic trace elements in Kazakhstan based on reviews of available scientific data. Environmental Science and Pollution Research, 2021, 28 (32), pp.4331543328. 10.1007/s11356-021-14979-z . hal-03275103v2

\section{HAL Id: hal-03275103 \\ https://hal.univ-lorraine.fr/hal-03275103v2}

Submitted on 1 Jul 2021

HAL is a multi-disciplinary open access archive for the deposit and dissemination of scientific research documents, whether they are published or not. The documents may come from teaching and research institutions in France or abroad, or from public or private research centers.
L'archive ouverte pluridisciplinaire HAL, est destinée au dépôt et à la diffusion de documents scientifiques de niveau recherche, publiés ou non, émanant des établissements d'enseignement et de recherche français ou étrangers, des laboratoires publics ou privés.

\section{(ㄷ)(1) $\$$}

Distributed under a Creative Commons Attribution - NonCommerciall 4.0 International 


\title{
Evaluation of environmental contamination by toxic trace elements in Kazakhstan based on reviews of available scientific data
}

\author{
Almagul Baubekova ${ }^{1}$ Ainisa Akindykova ${ }^{1}$ Aigerim Mamirova ${ }^{1}$ Camille Dumat $^{23}$ • \\ Stefan Jurjanz ${ }^{3}$ \\ a Faculty of Biology and Biotechnology, Al-Farabi Kazakh National University, \\ Almaty, Kazakhstan \\ b Centre d'Etudes et de Recherches Travail Organisation Pouvoir (CERTOP), \\ Université de Toulouse INP-ENSAT, Auzeville-Tokisane, France \\ c URAFPA, INRAE, Université de Lorraine, Nancy, France
}

Published in ESPR. Available online: https://link.springer.com/article/10.1007/s11356021-14979-z

\author{
Keywords \\ Kazakhstan $\bullet$ Metals $\bullet$ Soil - Sediments $\bullet$ Water $\bullet$ Sustainability $\bullet$ Risk management
}

\begin{abstract}
The environmental situation concerning pollution by (eco)toxic and persistent trace elements in Kazakhstan has been investigated by analytical reviews of scientific studies published over the past 20 years reporting concentrations of 10 toxic trace elements (TTE) observed in soil, sediments or surface water. A database of 62 articles published in Kazakh, Russian or English covered the majority of the territory of the country for soil and water samples but to a lesser extent for sediments. Reported concentrations were summarized using statistical parameters, then spatialized and finally classified in contamination classes according to local legislation. This analysis revealed some hotspots of TTE in surface waters ( $\mathrm{Cd}$ and $\mathrm{Pb}$ ), soil (As) and sediments ( $\mathrm{Cd}$ and $\mathrm{As}$ ). Hotspots of less toxic $\mathrm{Cu}, \mathrm{Zn}$ and $\mathrm{Mn}$ were also detected. Spatialization of results allowed localization of these hotspots close to industrial sites, such as smelters or mining and metallurgic combines. Others have been shown to be close to disused mining sites or landfills with municipal waste. Methodological improvements for further studies have been suggested, such as to integrate more West Kazakhstan or remote areas in sampling campaigns, but also to describe more exhaustively the used analytical methods and to be more attentive to the speciation of the analyzed form of the element. Finally, a management strategy to strengthen a sustainable food policy has been proposed: to reduce emissions by modernization of industrial facilities and better waste management, to organize land use depending on the contamination levels and to reduce the bioavailability of the toxic elements.
\end{abstract}

\section{Introduction}

Kazakhstan is a landlocked country in Central Asia having the ninth largest territory in the world with $2724 \mathrm{~km}^{2}$, but a population of only 18 million inhabitants, distributed very heterogeneously. There are three, densely populated large cities with over one million inhabitants: the capital NurSultan, Almaty and Shymkent. In contrast, only very few people live in the center or the west of the country. The sheer size of such territory makes the implementation of a rigorous environmental management of human activities exceedingly difficult, and need therefore to increase the education of all the citizens.

Ranking third of the industrial powers in the Commonwealth of Independent States, Kazakhstan has considerable mineral resources (copper, gold, iron, lead, titanium and zinc) and its economy was mainly built on mining and heavy industry. Indeed, there are more than 5000 mineral deposits and, consequently, facilities for concentration of metal ores (KazakhMys in East Kazakhstan, Nova Zinc in Akshatau, Aktyubinsk Copper Corporation in the Aktobe region or Yuzhpolimetall in Turkestan region) and finally different metal smelters as KazZinc (Oskemen and Ridder in the East) or KazakhMys (Karagandy region) (Brunet 2001; Safirova 2019). As a consequence of these numerous anthropogenic activities with metal emissions into the environment, persistent historic pollutions are observed today (Akhmetsadykova 2012; Shepelev 2017). Moreover, the dispersions of pollutants in the environment and contamination of food chains are facilitated by strong erosions and droughts in 
Kazakhstan, both due to soil structure fragility and continental climate. The climate change could increase the frequency of strong precipitations with consequences for transfer and dispersion of pollutants.

Today, a crucial challenge for Kazakhstan is conciliating the exploitation of metals necessary for the economic development of the country and limiting their emission into the environment. This will help protect natural resources, the food chains and, thus human health. Indeed, environmental pollutions with toxic trace elements (TTE) as heavy metals have become one of the serious ecological problems near large cities or industrial complexes in Eastern and Northern Kazakhstan as well as on petrol exploration sites in Mangystau or mining sites in Southern Kazakhstan (Brunet 2001). The contamination of environmental matrices, such as soil, but also of the aquatic chain (i.e. sediments and water) reflects emitting activities over a long period. It therefore seems necessary to inventory TTE measurements carried out on the territory of Kazakhstan and to evaluate them afterwards. An evaluation should focus on local norms and regulations that can then be extended by comparison with toxicological thresholds and regulations of other countries.

In this way, the aim of the present article is to analyse the environmental metal pollutions revealed in the country and to link them to their potential source(s). All scientific publications of the last 20 years reporting concentrations of TTE in environmental matters sampled on the territory of the Republic of Kazakhstan were analyzed. Hence, this article represents a very large literature overview of the situation concerning environmental pollution by TTE and offers a new view of the environmental state in Kazakhstan in order to give concrete perspectives to improve environment and food qualities.

\section{Material and Methods.}

\subsection{Data Collection}

The literature research was performed until February 2020 using different research databases (Web of Science, Google Scholar and Scopus) to extract peer-reviewed articles published in local academic journals in Russian or in Kazakh but also articles from internationally referenced journals published in English. Moreover, data from a governmental monitoring survey on trace elements in soils, sediments and water (GMS 2019) has been added. The data were integrated if sampling had been made on the territory of the Republic of Kazakhstan and the results reported field concentrations of TTE in soil, sediments or surface water. Water has been defined as only surface water focusing on the effects of anthropogenic emissions, and no analysis of groundwater has been taken into account. Finally, the reported concentrations should reflect a "not induced" pollution, i.e. artificial contaminations of environmental matrices for experimental purposes ("spiking") have been excluded. Then, the concentrations of elements have been extracted from the tables or - if not available from the figures - in the article. Each recorded data corresponded to the mean concentration issued from one studied modality mentioned in the article, representing generally one specific place at one specific moment. This data is sometimes the result of several elementary analyses (expressed as a mean) but sometimes only of one replica carried out by the authors. In this way, 62 studies listed in table S1 (supplementary material) have been browsed reporting TTE measurements in at least one of the three studied matrices. They have been carried out over the period 2002 to 2020 and covered all administrative regions of Kazakhstan as illustrated in figure 1.

These studies reported, in decreasing frequency, concentrations of copper, zinc, lead, cadmium, chromium, manganese and nickel, but also to a lesser extent, arsenic, mercury and cobalt. In soil, numerous elements were indicated as total concentration or their mobile fraction, which were recorded separately. Except clear indications in the article, we considered that an acid extraction would measure the total concentration, and a $\mathrm{pH}$ neutral extraction (i.e. aqueous phase or salt extraction with $\mathrm{CaCl}_{2}$ ) would indicate the mobile fraction of the element. In absence of such distinction in sediment or water, concentrations were expressed as total concentration of the considered element. Moreover, the content of the very toxic hexavalent form of $\mathrm{Cr}$ has been noted separately from total concentration, when available.

Additional data as geographic coordinates (GIS) of sampling points (given in the article or estimated by us), the potential emitting source(s), the sampling time and analytical specificities have also been noted in order to interpret reported concentrations.

Thus, the realized data set was composed by 3558 individual concentrations of 10 toxic trace elements, mainly heavy metals, published in 62 articles.

\subsection{Analysis of extracted concentrations}

Firstly, statistical parameters were carried out separately for each element in each matrix, starting with the number (noticed $\mathbf{n}$ ) of samples under the limit of quantification (LQ; used in the published study) $\left(\mathbf{n}_{(<L Q)}\right)$. Then the normality of the distribution of the concentration data, collected from very different studies, was checked by a Shapiro-Wilk test according to the methodology of (Danieli et al. 2012). Then, the mean concentration of all quantified samples (arithmetic but also geometric average), the $95^{\text {th }}$ percentile (the "upper group" without isolated outliers) and the maximum concentration were determined using only the quantified concentrations, i.e. excluding concentrations $<L Q$. Then, the parameters were summarized in form of violin plots and box plots for each element in each matrix calculated using the software $R$ (version 1.3.959, R Studio PBC, 2020). Adobe Illustrator CC (version 22.0.1, Adobe, 2018). Finally, the violin plots of all matrices were grouped in one synthetic figure per matrix. 
Secondly, a spatialization of different sampling places as well as revealed hotspots (i.e. high or extremely high concentration data for a given element in a given matrix, see also classification in table 1) on the Kazakh territory was carried out using NextGIS QGIS version: 20.2.0 (qgis.osgeo.org). The geographic coordinates (GIS) of the points were either indicated in the article or calculated from the geographic details mentioned in the article. Moreover, emission sources near these hotspots were revealed.

Thirdly, all individual concentration data were sorted by a classification according to their contamination level in comparison to reference values. The chosen comparison scales were national regulations. Therefore, all concentration data were classified based on thresholds, which derive from the Kazakh soil regulation (2004). Moreover, Kazakh standards for environmental safety (2015) distinguish four safety levels for soil uses: safe (we use the term "lightly contaminated" LC, based on natural concentrations in soil without anthropogenic activities), moderately contaminated (MC: 10 times higher than the concentration considered as safe), heavily contaminated (HC: up to 25 times higher than the considered safe concentration) and extremely contaminated (EC) soils (more than 25 times higher than considered safe concentration). Thus, all thresholds were a multiple of the initial LC level, which was considered as the "safe" level.

This regulation expresses the content of the element in soil as the total concentration $(\mathrm{Cu}, \mathrm{Pb}, \mathrm{Mn}, \mathrm{As}$, and $\mathrm{Hg})$ or the mobile fraction (Co). All elements or fractions missing in this regulation (i.e. total concentrations of $\mathrm{Zn}, \mathrm{Cd}, \mathrm{Ni}, \mathrm{Cr}$ and $\mathrm{Co}$ as well as the mobile fractions of $\mathrm{Pb}$ and $\mathrm{Mn}$ ) have been classified according to the Russian soil regulation (2006). Indeed, this standard can be considered as the root of Kazakh regulations because of its origin from former Soviet Union regulations, which has been in force up to its replacement by national regulations after the creation of the Republic of Kazakhstan. Thus, all threshold concentrations to classify elements (total or its mobile form) in soil were presented in table 1.

The concentration data of all elements in surface water have been classified according to Kazakh water guidelines (2015) concerning "water sources destined for household purposes except drinking". The safe level (i.e. LC) corresponded to the concentration data in water under the level indicated in these guidelines. Concentration data up to 10 times more were classified as moderately contaminated $(\mathrm{MC})$ and as highly contaminated $(\mathrm{HC})$ when 10 times exceeded as shown in table 1. The definition of the EC class corresponded to concentration data 25 times higher than the "safe" level despite the fact that in surface water no such high concentrations were revealed.

Finally, no specific guidelines for the concentrations in sediments were available in neither the Republic of Kazakhstan nor the Russian Federation. Numerous countries edited such guidelines to evaluate the quality of their sediments, but the threshold concentrations varied largely between them, which may be attributed to national specificities. Therefore, the most restrictive guidelines have been chosen to determine the safe or LC level, corresponding to the quality level in the guidelines of the Canadian State of Ontario (CCME 2008). We then applied the same multiplication steps as previously in soil to determine the higher levels: the moderately contaminated (MC) sediments correspond up to 10 times of these concentrations, heavily contaminated $(\mathrm{HC})$ to more than 10 times and finally extremely contaminated (EC) corresponding to 25 times higher than the "safe" threshold (i.e. LC).

All these classification thresholds have been summarized in table 1. Moreover, revealed hotspots, i.e. highest outliers, were presented and discussed in the context of local emission source(s).

\section{Results}

The statistical parameters of the distribution of each element in each matrix are presented in table 2. Their distribution was shown as violin plots in figure 2 separately for each of the studied environmental matrices soil (total element and mobile fraction), sediments and surface water respectively in the figures $2 a, 2 b, 2 c$ and $2 d$. Finally, the frequency of data within the different contamination classes have been summarized in table 3 .

Generally, much more concentration data in soil $(n=1478)$ and surface water $(n=1305)$ were available than in sediments $(n=775)$. The frequency of analyses permits to distribute the elements in three main groups:

- very frequently measured $(>500$ individual concentration data) were $\mathrm{Cu}(\mathrm{n}=667), \mathrm{Zn}(\mathrm{n}=603)$, $\mathrm{Pb}(\mathrm{n}=593)$ and $\mathrm{Cd}(\mathrm{n}=503)$.

- intermediate frequency of analysis for $\mathrm{Cr}(\mathrm{n}=344)$, $\mathrm{Mn}(\mathrm{n}=252)$ and $\mathrm{Ni}(\mathrm{n}=247)$

- rarely analyzed (<150 concentration data) were As $(n=143), \mathrm{Hg}(n=127)$ and especially Co $(n=79)$.

The results were presented below separately for the terrestrial and the aquatic environment. The elements were grouped within both environmental media by their toxicity presenting inside the main hotspots or highest values with their potential emission sources nearby. Indeed, we renounced to a detailed presentation of mean concentration data, always available in table 2 or figures 2 , which seems less relevant at the level of a country.

\section{Highly toxic elements}

Generally, the mean cadmium contamination was modest with 0.5 or $0.75 \mathrm{mg} \mathrm{Cd} \mathrm{kg}^{-1}$ soil respectively for the total and mobile fraction (table 2). Nevertheless, several hotspots were revealed (figure 3) with the highest data from the town of Shymkent (without indications about the precise sampling place) where the spring sample was reported at $32.2 \mathrm{mg} \mathrm{kg}^{-1}$ (GMS 2019). Several hotspots have also been mentioned around the metal smelters in East Kazakhstan (towns Ridder and Oskemen) especially in the residential zone at $1.5 \mathrm{~km}$ from the smelter, with soil concentrations 
systematically $>15 \mathrm{mg} \mathrm{kg}^{-1} \mathrm{Cd}$ and a maximum of $27.4 \mathrm{mg}$ $\mathrm{kg}^{-1}$ (Woszczyk et al. 2018). This general tendency was confirmed, but with lower concentrations, by other studies for the same smelter in Oskemen (Boluspaeva and Panin 2012) and another KazZinc smelter in the town of Ridder (Kirshibaev et al. 2012). The Cd concentrations decreased rapidly with the distance to the smelter to be $<10 \mathrm{mg} \mathrm{kg}^{-1}$ when the soil was sampled at more than $2 \mathrm{~km}$. Another hotspot had been reported near Almaty around the Karasai landfill with compacted municipal waste (Kaliaskarova et al. 2019). Excluding samples, which have been taken within the landfill, soil samples of 12 to $18 \mathrm{mg} \mathrm{Cd} \mathrm{kg}^{-1}$ were reported at some hundred meters around. Finally, a last hotspot appeared in West Kazakhstan around the Caspi Cement factory (near the village of Shetpe, Mangystau region) reported by Kenzhetayev et al. (2018). They reported soil concentrations of 8 to $10 \mathrm{mg} \mathrm{kg}^{-1}$ at sampling sites situated at less than $2.5 \mathrm{~km}$ from this factory (figure 3 ). The $\mathrm{Cd}$ contents in the aquatic chain remained generally modest with geometric means at $0.32 \mathrm{mg} \mathrm{kg}^{-1}$ in sediments and $1 \mathrm{\mu g} \mathrm{L}^{-1}$ in water (table 2). The maximum has been reported in sediments of the delta of the River Ili emptying into the Balkhash Lake with $6.2 \mathrm{mg} \mathrm{Cd} \mathrm{kg}^{-1}$ (Moore et al. 2003). Highest concentrations of 14 to $77 \mu \mathrm{g} \mathrm{Cd} \mathrm{L}^{-1}$ were reported in the surface water of rivers Tikhaya and Breksa in the town of Ridder (East Kazakhstan) by Yanygina and Evseeva (2019) with a hotspot at $182 \mu \mathrm{g} \mathrm{L}^{-1}$ (figure 3).

Soil samples averaged at 22.3 and $0.8 \mathrm{mg} \mathrm{kg}^{-1}$ respectively for total and mobile lead. Real hotspots were reported around the KazZinc metal smelters especially in the towns of Ridder and Oskemen with $>500 \mathrm{mg} \mathrm{kg}^{-1}$ at less than 2 $\mathrm{km}$ of the industrial area (Woszczyk et al. 2018). The

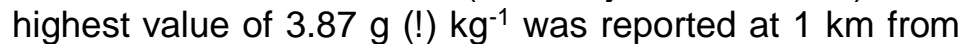
the KazZinc facilities in Oskemen by the governmental monitoring report (GMS 2019). This survey indicated also hotspots around the metal treatment factories of the Yuzhpolimetall Corp. in Kentau with 600 to $700 \mathrm{mg} \mathrm{kg}^{-1}$ and even 1.2 to $1.5 \mathrm{~g} \mathrm{~kg}^{-1}$ at $0.5 \mathrm{~km}$ of their industrial facilities in the town of Shymkent (Turkestan region). Finally, seriously increased lead concentrations in soil of $870 \mathrm{mg} \mathrm{kg}^{-1}$ were reported beside the Balkhash Mining and Metallurgical Combine (BMMC) (GMS 2019) (figure 3). The lead concentrations in the aquatic chain were much lower than in soil with a geometric mean of $2 \mathrm{mg} \mathrm{kg}^{-1}$ in sediments and $10 \mathrm{\mu g} \mathrm{L}^{-1}$ in surface water (table 2). The highest data in sediments of $124 \mathrm{mg} \mathrm{Pb} \mathrm{kg}^{-1}$ were reported in the northwest part of the Lake Balkhash, by the way close to BMMC (Sharipova 2015). The highest value in water has been reported by (Burlibayev et al. 2013b) for the River Arys in Turkestan with $2.6 \mathrm{mg} \mathrm{L}^{-1}$ (figure 3). By the way, Krupa et al. (2017) reported that in the basin of this particular river, one of the main tributary to the River Syr Darya, the presence of cement factories and important industrial waste dumps of the Yuzhpolimetall Corp.

The concentration of total chromium and its mobile fraction averaged in soil respectively 61.1 and $0.5 \mathrm{mg} \mathrm{kg}^{-1}$ (table 2). Over $70 \%$ of the available measurements in soil investigated its mobile fraction without revealing real hotspots. The mean concentrations of total $\mathrm{Cr}$ were at 0.7 $\mathrm{mg} \mathrm{kg}^{-1}$ and $4 \mathrm{\mu g} \mathrm{L}^{-1}$ respectively in sediments and surface water (table 2) without a real hotspot in sediments. In water, the very toxic hexavalent $\mathrm{Cr}$ has been investigated in 38 samples out of 99 with some concentrations $>100 \mu \mathrm{g} \mathrm{Cr}^{6+}$ $\mathrm{L}^{-1}$ in the River Elek just downstream the town of Aktobe (figure 3) and a maximum of $273 \mu \mathrm{g} \mathrm{Cr}^{6+} \mathrm{L}^{-1}$ measured during the dry autumn (GMS 2019).

The soil concentration of arsenic was $31.2 \mathrm{mg} \mathrm{kg}^{-1}$ (table 2). Numerous samples with really high concentrations reflected real problems at different places in Kazakhstan, such as $38 \mathrm{mg} \mathrm{kg}^{-1}$ reported by Salbu et al. (2013) at the ancient Uranium mining site of Kurday (Zhambyl region), but also 32 to $46 \mathrm{mg} \mathrm{kg}^{-1}$ in the coastal zone of the River Ili and 72 to $75 \mathrm{mg} \mathrm{kg}^{-1}$ the Northern Balkhash region (Tilekova et al. 2015). The highest concentrations of 721 $\mathrm{mg} \mathrm{kg}^{-1}$ were reported for the Vasilkovsky gold ore deposit near Kokshetau (Akmola region) by Tazitdinova et al. (2019) (figure 3). In comparison to soil, its concentrations in sediments seem less problematic as their geometric means was at $2.5 \mathrm{mg} \mathrm{kg}^{-1}$ and no reported concentration exceeded $20.2 \mathrm{mg} \mathrm{kg}^{-1}$ measured on the Mangystau coast of the Caspian Sea. In surface water, the revealed concentrations were less worrying with an average of $3 \mathrm{\mu g} \mathrm{L}^{-1}$ (table 2) with a maximum at $70 \mathrm{\mu g} \mathrm{L}^{-1}$ in the Aral Sea reported by Rzymski et al. (2019).

With regard to soil, only 19 analyses of total mercury were available which averaged at $0.2 \mathrm{mg} \mathrm{kg}^{-1}$ (table 2). Despite a maximum of $19 \mathrm{mg} \mathrm{kg}^{-1}$ reported in the Northern Industrial zone of Pavlodar (Panin and Geldymamedova 2006) (figure 3 ), one third of the $\mathrm{Hg}$ concentrations in soil were indicated $<L Q$ (table 2, figure 2a). The highest mercury concentrations in sediments were issued from one single study (Ullrich et al. 2007) focusing on $\mathrm{Hg}$ contamination near a derelict chloralkali plant in Pavlodar (Northern Kazakhstan) (figure 3). The concentrations in surface sediments of the storage lake were extremely high $(152 \mathrm{mg}$ $\mathrm{kg}^{-1}$ on average of 23 individual samples of $0-2.5 \mathrm{~cm}$ sediments) and contrast with concentrations reported in the same study in surface sediments of the River Irtysh and its oxbow lakes of 0.007 and $0.17 \mathrm{mg} \mathrm{kg}^{-1}$, respectively. Nevertheless, the other 28 sediment samples (out of 32 , figure 2c) did not exceed $3 \mathrm{mg} \mathrm{kg}^{-1}$ (GMS, 2019) for the River Nura (Karagandy region). The geometric mean of the data from surface water of $5.1 \mathrm{ng} \mathrm{L}^{-1}$ hides large variations (table 2). Ullrich et al. (2007) reported from the water of the same storage lake a median concentration of $1 \mu \mathrm{g} \mathrm{L}^{-1}$ but also a maximum concentration of $7.5 \mu \mathrm{g} \mathrm{L}^{-1}$ at $200 \mathrm{~m}$ from the outfall point. Finally, Slivinsky et al. (2009) reported 4 $\mu \mathrm{g} \mathrm{L}^{-1}$ in a wastewater channel of the Termitau Karagandy industrial complex (Karagandy region).

\section{Less toxic elements}

In comparison to the previously highly toxic elements, the following elements are generally much less toxic, even with relatively high concentrations.

The geometric means in soil were at 12.9 and $3.0 \mathrm{mg} \mathrm{kg}^{-1}$ respectively for total copper and its mobile fraction (table 2). Maximum values in soil were reported always in the same zone of the town of Oskemen with $856 \mathrm{mg} \mathrm{kg}^{-1}$ (Woszczyk et al. 2018). Another hotspot around the town of 
Balkhash and its Mining and Metallurgic combine (BMMC) measured $133 \mathrm{mg}$ of mobile Cu kg-1 (GMS 2019) (figure 3). Its concentrations of mobile fraction around the sites of Yuzhpolimetall Corp in Shymkent were reported between 40 and $80 \mathrm{mg} \mathrm{kg}^{-1}$. In sediments, $\mathrm{Cu}$ concentrations averaged at $3.3 \mathrm{mg} \mathrm{kg}^{-1}$ (table 2) with hotspots of $220 \mathrm{mg}$ $\mathrm{kg}^{-1}$ in sediments of the River Shilosek near Kurday (Zhambyl Region) beside an ancient uranium mining site (Salbu et al. 2013) but also up to $211 \mathrm{mg} \mathrm{Cu} \mathrm{kg}^{-1}$ in sediments sampled in the northwest (Bertys Bay and Torangalyk Bay) of the Lake Balkhash (Sharipova 2015) (figure 3), The latter may be attributed to the previously mentioned BMMC plant nearby. The $\mathrm{Cu}$ concentration in surface water averaged at $10 \mu \mathrm{g} \mathrm{L}^{-1}$ (table 2). Nevertheless, high concentrations between 1 and $6 \mathrm{mg} \mathrm{L}^{-1}$ have been reported along the River Syr Darya by Mustafayev et al. (2017a) but also an absolute hotspot of $18,8 \mathrm{mg} \mathrm{L}^{-1}$ in the River Saryozek close to the Altay Polymetals LLP in the sub-region of Karkaraly (Karaganda region) (figure 3) by the governmental survey (GMS 2019).

Zinc concentrations in soil averaged at 38.7 and $15.9 \mathrm{mg}$ $\mathrm{kg}^{-1}$ respectively for the total and its mobile fraction (table 2). Different studies in the industrial zones of the towns of Oskemen and Ridder reported concentrations exceeding 1 $\mathrm{g} \mathrm{Zn} \mathrm{kg}^{-1}$ as previously mentioned for $\mathrm{Cd}$ and $\mathrm{Pb}$. The maximum of $2.4 \mathrm{~g} \mathrm{Zn} \mathrm{kg}^{-1}$ came from the residential zone in Oskemen at $1.5 \mathrm{~km}$ from the KazZinc smelter (Woszczyk et al. 2018) (figure 3). Geometric mean of the zinc concentration data was $4.9 \mathrm{mg} \mathrm{kg}^{-1}$ in sediments and $20 \mu \mathrm{g}$ $\mathrm{L}^{-1}$ of surface water. No real hotspots have been reported in sediments, but high concentration in surface water were published again for the River Syr Darya between the town of Kyzylorda and the Aral sea (Mustafaev et al. 2017b) with several points between 5 and $8.8 \mathrm{mg} \mathrm{Zn} \mathrm{L}^{-1}$ (figure 3 ).

The mean concentration of nickel in soil was 31.6 and 2.8 $\mathrm{mg} \mathrm{kg}^{-1}$ respectively for total and mobile form (table 2). Without real hotspots, some slightly elevated concentrations around $60 \mathrm{mg} \mathrm{kg}^{-1}$ were reported in the town of Almaty (Mynbaeva 2012), up to $80 \mathrm{mg} \mathrm{kg}^{-1}$ close to the KazakhMys smelter north of the Lake Balkhash (Karagandy region) (Tilekova et al. 2015) and concentration maximum of nearly $160 \mathrm{mg} \mathrm{Ni} \mathrm{kg}^{-1}$ in the industrial zone of Pavlodar (Panin and Geldymamedova 2006). In sediments, nickel averaged at $3.8 \mathrm{mg} \mathrm{kg}^{-1}$ and a maximum of $54.9 \mathrm{mg} \mathrm{kg}^{-1}$ was reported in the delta of the River Zhayik (Ural river) in the Caspian Sea (de Mora et al. 2004) (figure 2c). The geometric mean in surface water was at $11 \mathrm{\mu g} \mathrm{Ni} \mathrm{L}^{-1}$ (table 2). Several samples of lightly contaminated surface water have been reported at $101 \mathrm{\mu g} \mathrm{L}^{-1}$ for the ancient mining site Kurday (Zhambyl region) (Salbu et al. 2013), $118 \mu \mathrm{g} \mathrm{L}^{-1}$ in the Kapshagay reservoir north of Almaty (Amirgaliev and Ismukhanova 2013), 107 to $152 \mu \mathrm{g} \mathrm{L}^{-1}$ in different rivers around Kostanay at the Russian borderline (Kostanay region) and finally $254 \mu \mathrm{g} \mathrm{L}^{-1}$ in the water reservoir beside the Lake Sarykol (GMS 2019). A real hotspot of $2.62 \mathrm{mg}$ (!) $\mathrm{L}^{-1}$ was reported by Slivinski and Krupa (2013) in the lake Tengiz (Akmola region) measured during the dry July where elements concentrated in a reduced water volume (figure $3)$.
Manganese concentrations in soil averaged at $562 \mathrm{mg} \mathrm{kg}$ ${ }^{1}$ (table 2) with the highest concentration of $1784 \mathrm{mg} \mathrm{kg}^{-1}$ in the industrial area of the town of Pavlodar (Panin and Geldymamedova 2006) (figure 2b). In sediments and surface water, geometric means for Mn were respectively $29.1 \mathrm{mg} \mathrm{kg}^{-1}$ and $30 \mathrm{\mu g} \mathrm{L}^{-1}$ (table 2). No real hotspots were noticed for sediments but in surface water, samples over 1 $\mathrm{mg} \mathrm{L}^{-1}$ were reported (GMS 2019) for the River Kylshykty (Akmola region) and $3.36 \mathrm{mg} \mathrm{L}^{-1}$ for the River Saryozek (Karagandy region) close to Altay Polimetal LLP cited previously for its copper hotspot (figure 3).

Finally, 26 cobalt concentration data in soil were available, within four expressed only the mobile fraction. The mean of total Co was at $12.6 \mathrm{mg} \mathrm{kg}^{-1}$ soil (table 2) with a maximum of $63.4 \mathrm{mg} \mathrm{kg}^{-1}$ reported for the eastern industrial zone of Pavlodar (Panin and Geldymamedova 2006). Only 7 concentrations of Co were found in sediments with an average of $5.8 \mathrm{mg} \mathrm{kg}^{-1}$ and a maximum of $12.3 \mathrm{mg} \mathrm{kg}^{-1}$ in the River Topar (Almaty region) close to its mouth in the River Ili (Shalakhmetova et al. 2018). The mean Co concentrations in surface water was at $4 \mu \mathrm{g} \mathrm{L}^{-1}$ with a very high result of $105 \mathrm{\mu g} \mathrm{L}^{-1}$ in the River Syr Darya (Zhang et al. 2020) near the town of Kyzylorda (figure 3).

\section{Classification of contamination levels}

The frequency of the different contamination levels of available data about HMs concentrations in soil, sediments and surface water are presented in table 3 .

Globally, the majority of revealed concentrations were classified in the two lowest contamination classes LC and MC. The most highly contaminated samples (i.e. classified $\mathrm{HC}$ or EC) represented $8.4 \%$ (124 out of 1478). Such high contaminations concerned $\mathrm{Cu}(21 / 302), \mathrm{Zn}$ (28/291), Pb (29/294), Cd (29/235) and As (17/44) but absence of highly contaminated soil samples were noticed for $\mathrm{Cr}, \mathrm{Mn}, \mathrm{Ni}, \mathrm{Hg}$ and Co. The problematic samples corresponded to the hotspots presented previously.

Highly contaminated samples were much rarer in sediments of which only 8 out $775(1 \%)$ were classified in $\mathrm{HC}$ or EC (table 3). The contaminations concerned sporadically Cu (2/117) and Cd (1/97) but more seriously

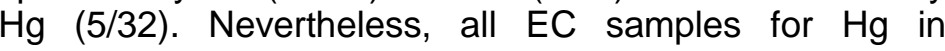
sediments were reported by the same study (Ullrich et al. 2007) and the specific sampling conditions have always been presented here above.

In surface water, 22 samples out of 1305 (1.7\%) were classified as $\mathrm{HC}$ (table 3$)$. They concerned sporadically $\mathrm{Ni}$ $(1 / 110)$ and $\mathrm{Cu}(1 / 248)$, but more frequently $\mathrm{Mn}(4 / 108)$ and especially $\mathrm{Pb}(7 / 182)$ and $\mathrm{Cd}(9 / 171)$. The corresponding hotspots of these highly contaminated water samples have been presented in the previous chapter. No revealed water concentration corresponded to the EC class.

Thus, $\mathrm{Cu}$ and $\mathrm{Cd}$ presented hotspots in all three matrices. Highly concentrations of $\mathrm{Pb}$ were revealed in soil and surface water. The other elements cause problems in only 
one specific matter: $\mathrm{Zn}$ and As in soil, $\mathrm{Hg}$ in sediments and finally $\mathrm{Mn}$ and $\mathrm{Ni}$ only in surface water (table 3).

\section{Discussion}

\section{Methodological considerations}

The majority of studies analyzed the elements via atomic absorption. Only four or three studies used methods based on respectively X-ray fluorescence or atomic emission and the most recent works used ICP-MS $(n=7)$. Despite these analytical differences, their performances seem adapted to the targeted concentrations of the elements. Indeed, few concentrations were reported $\angle \mathrm{LQ}$ in soil (only $\mathrm{Hg}$ : 6 out of 19) and sediments (only $\mathrm{Cd}$ : 22 out of 97 and $\mathrm{Pb}: 23$ out of 117). In contrast, nearly all elements (9 out of 11) measured in superficial water showed some samples $\angle L Q$ (figure $2 d$ ). Their proportion did generally not exceed $10 \%$ of the samples, except for $\mathrm{Hg}$ (38 samples out of 76). By the way, the $L Q$ in water was at least $0.1 \mu g \mathrm{~L}^{-1},(\mathrm{Co}, \mathrm{Mn}, \mathrm{Ni}$, and $\mathrm{Zn}$ ), but for the most elements at $1 \mathrm{ng} \mathrm{L} \mathrm{L}^{-1}$ (As, Cd, Cr, Cu, $\mathrm{Hg}, \mathrm{Pb})$ what appears consistent to the objectives.

We regret the low number of available analyses of the very toxic elements $\mathrm{Hg}$ and partially also As. Given their toxicity, they should be investigated more systematically, monitoring mercury concentrations in gold ore of Vasilkovsky.

The results of the actual monitoring program are published on governmental websites (www.ecogosfond.kz; www.kazhydromed.kz). These reports (such as GMS 2019) summarize the contents of the main metals $(\mathrm{Cd}, \mathrm{Cr}, \mathrm{Cu}, \mathrm{Pb}$, $\mathrm{Zn}$ and more sporadically $\mathrm{Ni}$ ) on the main towns of each region of Kazakhstan. They would gain informative value by a more detailed description of the used analytical methods, but also by precising the speciation of the measured elements. Indeed, special attention should be paid to the most toxic forms as $\mathrm{CH}_{3} \mathrm{Hg}, \mathrm{Cr}^{6+}, \mathrm{As}^{5+}$ or $\mathrm{Pb}^{2+}$.

Generally, the published articles presented only mean concentrations, although some studies reported large variations between the different sampling points, such as along the River Syr Darya in the article of Zhang et al. (2020). The publication of all realized analyses would allow a more detailed analysis in time and/or space and to focus the generally restricted remediation means precisely there. Finally, the assessment of the risk for the food chain would consider the bioavailable fraction of the TTE. The use of different protocols to determine the mobile or bioavailable fraction represented a difficulty to compare the results between different studies. While an element in water can be considered as mobile, this distinction in soil is more difficult and the evaluation of the bioavailable proportion of the total content bring a real add value to the analysis. Finally, it would be interesting to compare the measured concentrations in the soil to the geochemical background, for instance in the study of Woszczyk et al. (2018). Unfortunately, only a few studies considered this natural parameter.

\section{Geographic covering of the dataset}

The available data do not allow a complete pattern of the geographic distribution of TTE pollutions in Kazakhstan (figure 1). Indeed, the governmental monitoring focuses on the main towns and the extracted studies targeted generally specific hotspots. Whilst our dataset covers soil analyses in the industrial centers like Oskemen or around Almaty, information about remote regions in the center part of the country was almost non-existent. Indeed, few studies have been found about Western Kazakhstan, especially the regions of Aktobe and Mangystau, with respect to their exploration activities associated to the industrial facilities or the Baikonyr Cosmodrome. Sediment and water samples cover the biggest water reservoirs of the country as the Lake Balkhash, the River Syr Darya and the Northeast of the Caspian Sea, but the rivers Karasu and Irgiz (Karagandy and Aktobe regions) and Ertis (regions of the Northeast) have been poorly investigated. In contrast, very little is known about TTE contaminations in remote areas. Despite the absence of large industrial facilities in these areas, the local waste management, including metallic wastes, is poorly organized and could create a real risk of diffuse emissions. The large distances and sparse transport facilities to these remote areas complicate investigations locally.

Despite these limits, several outcomes can be taken from this dataset. The soil samples taken around the different metal smelters could be easily linked to places with $\mathrm{HC}$ or EC concentrations of $\mathrm{Cd}, \mathrm{Pb}$, and $\mathrm{Zn}$. Indeed, figure 3 illustrates that the EC concentrations in soil have been sampled around the metallurgic facilities in the East (towns of Ridder and Oskemen) the KazakhMys factory in the North Balkhash zone as well as the Yuzhpolimetall site in Shymkent. The concrete mixing plant in Kokshetau could be linked to extremely high concentrations of arsenic in soil. Soil samples taken in and around the largest city of the country, Almaty, showed mainly a contamination with Cd in water and soil, apparently linked to waste management in the Karasai landfill.

Few sediment samples were classified as HC or EC and has to be viewed in the context of the relatively low number of studies. Indeed, the dataset allows only investigating sediments from some specific sites but without information about others, such as big rivers like Ertis or Zhaiyk (figure 1). The reported analyses of sediments sampled on the Kazakh coast of the Caspian Sea or the Balkhash basin did therefore not reveal problematic contaminations.

In contrast, high contamination levels in different surface waters (rivers or reservoirs) were revealed around metal smelters or mining sites, especially for $\mathrm{Cd}, \mathrm{Pb}$ and $\mathrm{Mn}$ showing a clear impact of these activities (figure 3). Some other high concentrations, especially in the West, were measured during the dry season when low water level concentrated TTE.

These findings show that economic benefits gained from such industrial activities are offset by a very consequential ecological impact on soil and water near related industrial 
sites. Highlight these consequences is a crucial step to promote the changes of the industrial practices to reduce the environmental emissions.

\section{Consequences of environmental pollution on for the Food safety}

The shown high contamination levels of soil from certain places in Kazakhstan (hotspots) could induce risks for human health, particularly linked to contaminated food consumption (Kacholi and Sahu 2018; Dumat et al. 2019; Deng et al. 2020) or accidental soil ingestion, for instance throughout farming, gardening or leisure activities (Pascaud et al. 2014; Dumat et al. 2019). Contaminated surface water could also enhance an exposure of local populations when these sources were used for gardening, watering of farm animals or even in households. The use of surface water for these activities is favored by a difficult access to water in remote areas of several regions of the country, especially during the very continental summer. Moreover, exposure may act via food of animal origin, which is traditionally produced by extensively outside reared animals ingesting accidentally soil, and has been proven for the majority of species (Abrahams and Steigmajer 2003; Jurjanz et al. 2012, 2014). These facts have great significance in Kazakhstan where $80 \%$ of the agricultural land is classified as traditional pasture areas used by local people (Diacono et al. 2008) and the population has a traditionally staple meat diet (WHO 2019). Even the traditional Kazakh camel breeding based on an extensive mode and access to natural resources has been shown to be weakened by $\mathrm{Pb}$ and $\mathrm{Cd}$ pollution (Akhmetsadykova 2012). Tattibayeva et al. (2016) illustrated another example of the environmental effect of heavy metal contaminations on irrigated rice in Kazakhstan. Intuitively, it seems that the first step to reduce exposure of the population would be simply decreasing the emissions of the previously cited hotspot. Such simplistic solution has to be put in the economical context of a country where ore extraction and manufacturing represent $29 \%$ of the GDP (DTTL 2019) and paved the way for the reconstruction of the country after the collapse of the Soviet Union. Indeed, the importance of the heavy industry for the national economy of Kazakhstan underlines the need to maintain these sources of national wealth while reducing the environmental impact. Such compromises should go by a strong modernization of the industrial facilities to firstly reduce the emissions and secondly improve significantly waste management. A second step to reduce exposure of the population is aiming at an improved network of information for the local population concerning soil quality in order to develop adapted soil uses. Heavily contaminated surfaces as shown around some landfills should be excluded from residential areas or outdoor activities. Even food production can be adapted to a (light) presence of some TTEs as Kazakhstan adopted very largely a conservation agriculture (FAO 2017) by zero tillage, systematic land cover and crop rotation. Other factors also influence environmental and sanitary risks such as the solubility of pollutants, their mobility and transfers (promoted by low $\mathrm{pH}$ and poverty of organic matter in soil), the clay amount of soil (influencing soil structure and the trend of the soil to more or less adhere to the farmers' hands causing accidental ingestion), the presence of several pollutants and finally the average daily quantities of soil ingested or inhaled. These agroecological farmers' practices participate to halt soil erosion and increase finally food quality as metals transfers in the environment and soilbiosphere transfers are reduced.

Finally, the third step consists of a joint venture of scientific institutions and local authorities to raise the population's awareness of measures to reduce their exposure including washing and peeling of home-grown vegetables, reducing the consumption of offal, which can especially bioaccumulate some TTE, such as cadmium or simply improving drinking water supply in remote areas.

The assessment of the sanitary risk by the stakeholders needs to identify the main exposure scenarios and to build on it a strategy integrating all these levels: reduced emissions, function of the soil uses, adapted human practices and food habits.

\section{Conclusion}

The present synthesis of published concentration data concerning 10 toxic trace elements in environmental matrices on the territory of Kazakhstan during the last 20 years showed some very high contamination levels (hotspots), especially with the very toxic cadmium, lead and arsenic, but also with less toxic copper and zinc in the vicinity of industrial sites, mainly in soil and surface water. Although the majority of data was not within a dangerous range, some real hotspots were identified, mainly near sites of metal manufacturing in the East and the North of the country. Despite some limits of our approach, the presented pragmatic analysis of this enormous database gives on the one hand a very useful overview of the environmental situation in the country and indicates on the other hand some elements to improve significantly further field investigations in Kazakhstan, especially on targeted TTE, their speciation and sampling areas.

In order to promote a sustainable food policy development in Kazakhstan, these scientific findings may be a guide to focus on industrial sites where emissions have to be reduced, to adapt the land use to its contamination level and finally, to deploy a policy of education and protection of the local population to improve significantly the food safety and to decrease human exposure. 
Table 1. Classification thresholds of heavy metal concentrations in soil or sediments (mg kg-1 of dry matter) as well as in surface water $(\mu \mathrm{g} \mathrm{L}-1)$ according to local regulations.

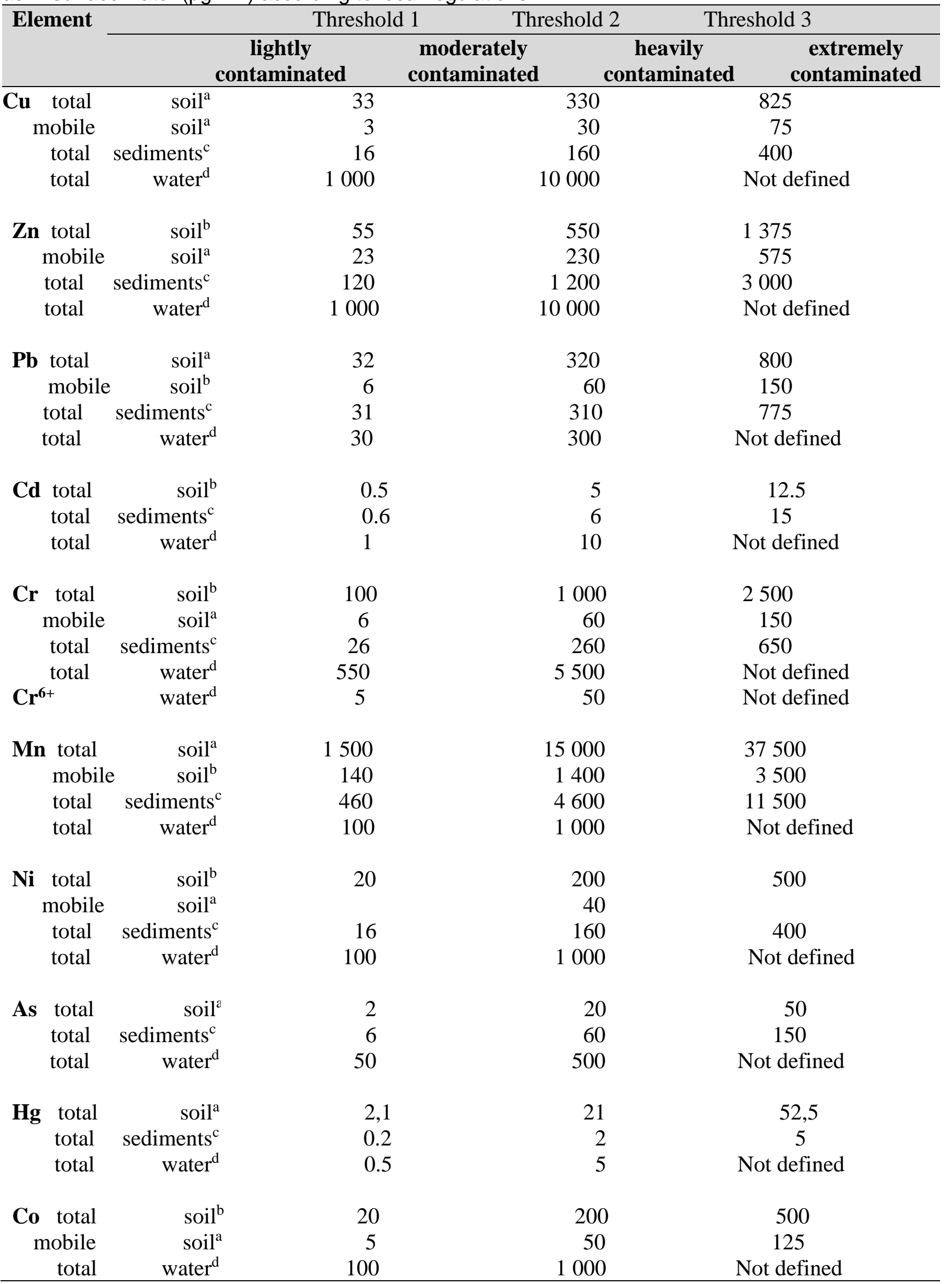


Table 2. Statistical parameters of the distributions of the reported concentration data of all analyzed toxic trace elements in soil, sediments and surface water in Kazakhstan.

\begin{tabular}{|c|c|c|c|c|c|c|c|c|c|}
\hline \multicolumn{3}{|c|}{ Element } & $\mathbf{n}_{\text {tot }}$ & $\mathbf{n}_{<\mathrm{LQ}}$ & Normality $^{\mathrm{a}}$ & G. mean $^{b}$ & A. mean $^{c}$ & $95^{\text {th }} \mathrm{pc}^{\mathrm{d}}$ & $\max ^{\mathrm{e}}$ \\
\hline \multirow[t]{4}{*}{$\mathbf{C u}$} & total & soil & 137 & - & no & 12.91 & 47.72 & 162.4 & 856.3 \\
\hline & mobile & soil & 165 & - & no & 3.03 & 12.29 & 63.6 & 132.8 \\
\hline & total & sediments & 117 & - & no & 3.33 & 12.32 & 42.9 & 220.0 \\
\hline & total & water & 248 & 10 & no & 0.01 & 0.37 & 3.0 & 18.8 \\
\hline \multirow[t]{4}{*}{$\mathbf{Z n}$} & total & soil & 107 & - & no & 38.72 & 220.82 & 1482.3 & 2406.3 \\
\hline & mobile & soil & 184 & - & no & 15.92 & 88.56 & 492.0 & 1136.6 \\
\hline & total & sediments & 102 & - & no & 4.91 & 11.39 & 56.8 & 119.9 \\
\hline & total & water & 210 & 9 & no & 0.02 & 0.51 & 3.8 & 8.8 \\
\hline \multirow[t]{4}{*}{$\mathbf{P b}$} & total & soil & 276 & - & no & 22.34 & 127.65 & 653.9 & 3875.2 \\
\hline & mobile & soil & 18 & - & no & 10.17 & 24.42 & 60.7 & 65.0 \\
\hline & total & sediments & 117 & 23 & no & 2.02 & 12.10 & 32.7 & 124.0 \\
\hline & total & water & 182 & 21 & no & 0.010 & 0.114 & 0.25 & 2.7 \\
\hline \multirow[t]{4}{*}{ Cd } & total & soil & 218 & - & no & 0.50 & 2.36 & 13.0 & 32.3 \\
\hline & mobile & soil & 17 & - & no & 0.76 & 2.48 & 5.5 & 6.8 \\
\hline & total & sediments & 97 & 22 & no & 0.32 & 0.64 & 1.6 & 6.2 \\
\hline & total & water & 171 & 13 & no & 0.001 & 0.005 & 0.01 & 0.18 \\
\hline \multirow[t]{4}{*}{$\mathrm{Cr}$} & total & soil & 41 & 1 & no & 61.13 & 77.86 & 146.2 & 448.7 \\
\hline & mobile & soil & 105 & - & no & 0.48 & 2.11 & 7.2 & 57.0 \\
\hline & total & sediments & 97 & - & no & 0.69 & 5.74 & 31.7 & 103.0 \\
\hline & total & water & 63 & 4 & no & 0.004 & 0.021 & 0.16 & 0.21 \\
\hline \multicolumn{2}{|l|}{$\mathrm{Cr}^{6+}$} & water & 38 & 5 & no & - & - & 0.19 & 0.27 \\
\hline \multirow[t]{4}{*}{ Mn } & total & soil & 44 & - & no & 562.47 & 648.31 & 1049.9 & 1784.3 \\
\hline & mobile & soil & 8 & 1 & no & 2.35 & 27.04 & 97.3 & 130.0 \\
\hline & total & sediments & 92 & - & no & 29.14 & 217.43 & 631.5 & 1080.0 \\
\hline & total & water & 108 & - & no & 0.03 & 0.21 & 0.77 & 3.4 \\
\hline \multirow[t]{4}{*}{$\mathbf{N i}$} & total & soil & 47 & - & no & 31.56 & 42.30 & 79.6 & 159.7 \\
\hline & mobile & soil & 22 & - & no & 2.77 & 3.96 & 8.6 & 8.9 \\
\hline & total & sediments & 68 & - & no & 3.84 & 7.87 & 30.9 & 54.9 \\
\hline & total & water & 110 & 1 & no & 0.011 & 0.05 & 0.11 & 2.7 \\
\hline \multirow[t]{4}{*}{ As } & total & soil & 30 & - & yes & 31.24 & 74.17 & 294.3 & 721.0 \\
\hline & mobile & soil & 14 & - & no & 0.85 & 1.43 & 2.5 & 2.7 \\
\hline & total & sediments & 46 & - & no & 2.49 & 3.34 & 8.8 & 20.2 \\
\hline & total & water & 53 & 9 & no & 0.003 & 0.01 & 0.05 & 0.07 \\
\hline \multirow[t]{3}{*}{ Hg } & total & soil & 19 & 6 & no & 0.23 & 2.01 & 9.7 & 19.0 \\
\hline & total & sediments & 32 & 1 & no & 0.11 & 9.54 & 62.5 & 151.5 \\
\hline & total & water & 76 & 38 & no & $5.12 \mathrm{E}-05$ & $3.14 \mathrm{E}-04$ & 0.001 & 0.004 \\
\hline \multirow[t]{4}{*}{ Co } & total & soil & 22 & - & no & 12.55 & 16.95 & 43.6 & 63.4 \\
\hline & mobile & soil & 4 & - & no & 0.09 & 0.23 & 0.7 & 0.8 \\
\hline & total & sediments & 7 & - & no & 5.77 & 6.75 & 12.2 & 12.3 \\
\hline & total & water & 46 & 6 & no & 0.004 & 0.010 & 0.05 & 0.11 \\
\hline
\end{tabular}

$\mathrm{n}$ tot total number of quantified concentration data

$\mathrm{n}<\mathrm{QQ}$ number of concentration data reported under the limit of quantification

a normality of distribution of residues tested by Shapiro test at the threshold $P<0.05$

${ }^{b}$ G. mean - geometric mean of all quantified concentration data

${ }^{c}$ A. mean - arithmetic mean of all quantified concentration data

d $95^{\text {th }}$ percentile

e maximum concentration data of the whole dataset 
Table 3. Sample frequency in contamination levels of toxic trace elements in soil, sediments and surface water in Kazakhstan

\begin{tabular}{|c|c|c|c|c|c|c|c|c|c|c|c|c|c|c|c|}
\hline \multirow[t]{2}{*}{ Element } & \multicolumn{5}{|c|}{ Soil } & \multicolumn{5}{|c|}{ Sediments } & \multicolumn{5}{|c|}{ Surface water } \\
\hline & $\mathbf{n}$ & LC & MC & $\mathrm{HC}$ & EC & n & $\mathbf{L C}$ & MC & $\mathrm{HC}$ & EC & n & $\mathbf{S}$ & $\mathbf{L C}$ & HC & EC \\
\hline \multirow{2}{*}{$\begin{array}{c}\mathbf{C u} \text { total } \\
\text { mobile }\end{array}$} & 137 & 77 & 59 & - & 1 & 117 & 97 & 18 & 2 & - & 248 & 228 & 19 & 1 & - \\
\hline & 165 & 72 & 73 & 14 & 6 & - & & & & & & & & & \\
\hline \multirow{2}{*}{$\begin{array}{l}\text { Zn total } \\
\text { mobile }\end{array}$} & 107 & 69 & 26 & 6 & 6 & 102 & 102 & - & - & - & 210 & 186 & 24 & - & - \\
\hline & 184 & 94 & 74 & 8 & 8 & - & & & & & & & & & \\
\hline \multirow{2}{*}{$\begin{array}{l}\text { Pb total } \\
\text { mobile }\end{array}$} & 276 & 153 & 95 & 16 & 12 & 117 & 111 & 6 & - & - & 182 & 125 & 50 & 7 & - \\
\hline & 18 & 7 & 10 & 1 & - & - & & & & & & & & & \\
\hline \multirow{2}{*}{$\begin{array}{l}\text { Cd total } \\
\text { mobile }\end{array}$} & 218 & 125 & 63 & 17 & 12 & 97 & 63 & 33 & 1 & - & 171 & 63 & 99 & 9 & -1 \\
\hline & 17 & $\mathrm{nc}^{\mathrm{a}}$ & & & & - & & & & & & & & & \\
\hline \multirow{2}{*}{$\begin{array}{l}\mathbf{C r} \text { total } \\
\text { mobile }\end{array}$} & 41 & 34 & 7 & - & - & 97 & 91 & 6 & - & - & 63 & 63 & - & - & - \\
\hline & 105 & 97 & 8 & - & - & - & & & & $\mathrm{Cr}^{6+}$ & 38 & 27 & 11 & - & -1 \\
\hline \multirow{2}{*}{$\begin{array}{l}\text { Mn total } \\
\text { mobile }\end{array}$} & 44 & 43 & 1 & - & - & 92 & 63 & 29 & & & 108 & 64 & 40 & 4 & - \\
\hline & 8 & 8 & - & - & - & - & & & & & & & & & \\
\hline \multirow{2}{*}{$\begin{array}{l}\text { Ni total } \\
\text { mobile }\end{array}$} & 47 & 9 & 38 & - & - & 68 & 59 & 9 & - & - & 110 & 100 & 9 & 1 & - \\
\hline & 22 & 14 & 8 & - & - & - & & & & & & & & & \\
\hline \multirow{2}{*}{$\begin{array}{l}\text { As total } \\
\text { mobile }\end{array}$} & 30 & - & 13 & 7 & 10 & 46 & 42 & 4 & - & - & 53 & 50 & 3 & - & -1 \\
\hline & 14 & $\mathrm{nc}^{\mathrm{a}}$ & & & & - & & & & - & & & & - & \\
\hline $\mathbf{H g}$ total & 19 & 17 & 2 & - & - & 32 & 24 & 2 & 1 & 4 & 76 & 38 & 38 & - & - \\
\hline Co total & 22 & 17 & 5 & - & - & 7 & $\mathrm{nc}^{\mathrm{a}}$ & & & & 46 & 45 & 1 & - & - \\
\hline mobile & 4 & 4 & - & - & - & - & & & & & & & & & \\
\hline
\end{tabular}


- Soil

A Sediment

- Water

All three matrices

O City

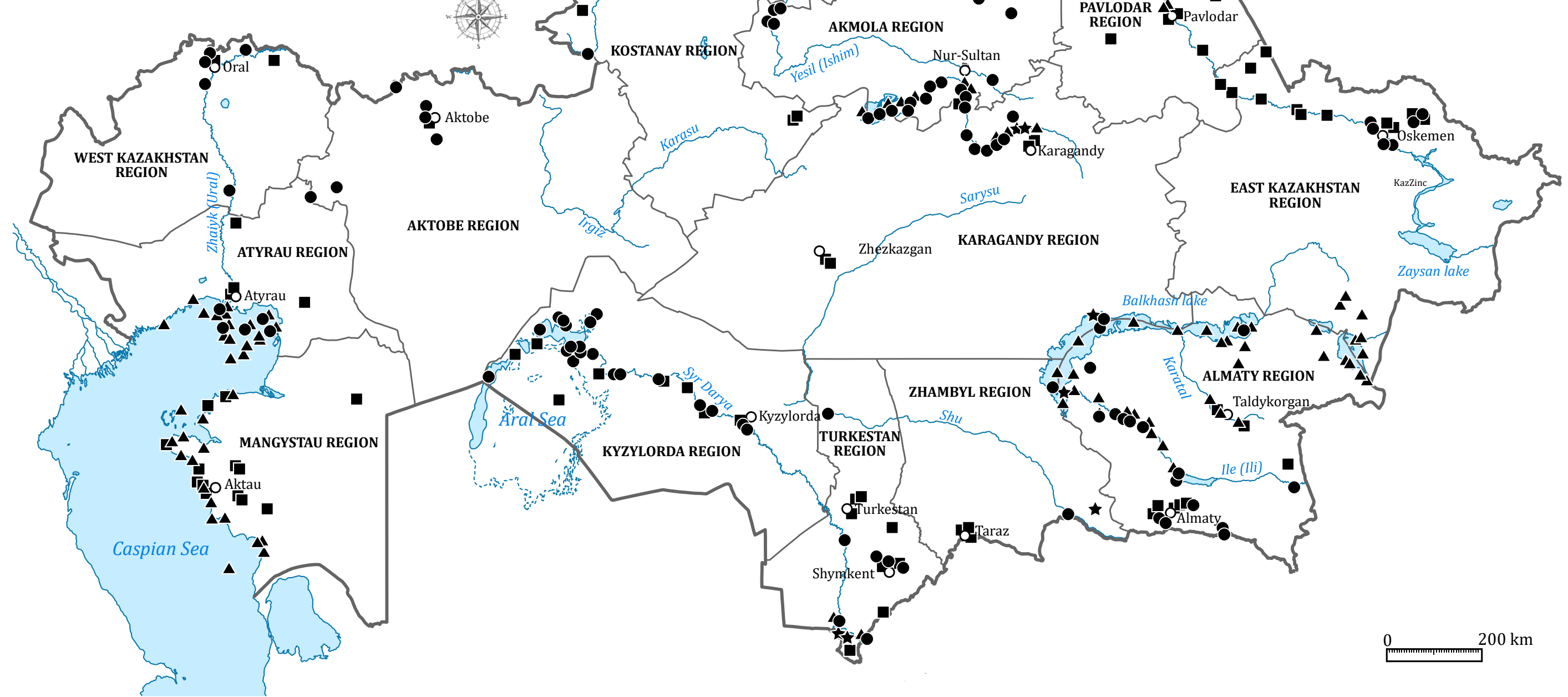

Figure 1. Sampling points for soil (square), sediments (triangle), and surface water (ring) on the territory of the Republic of Kazakhstan 


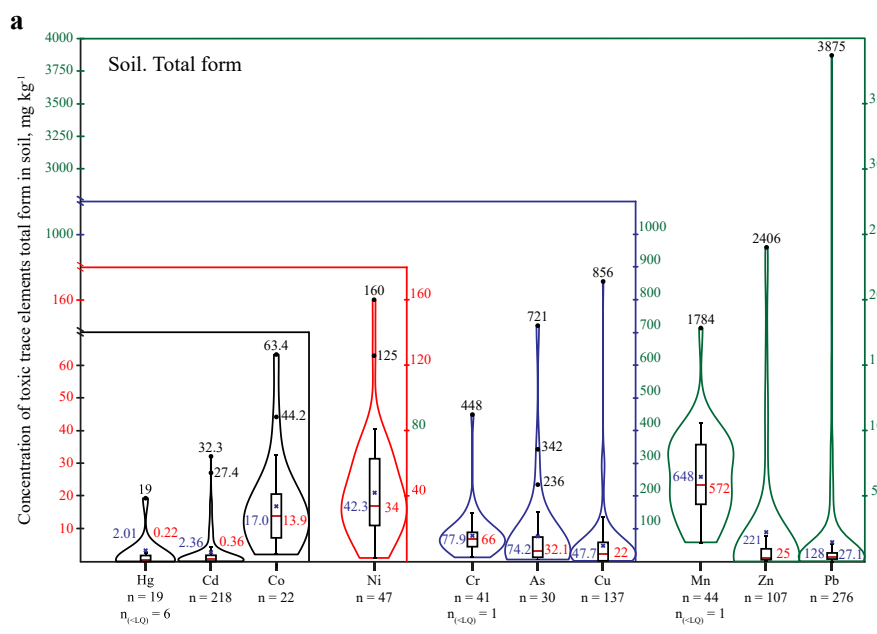

b
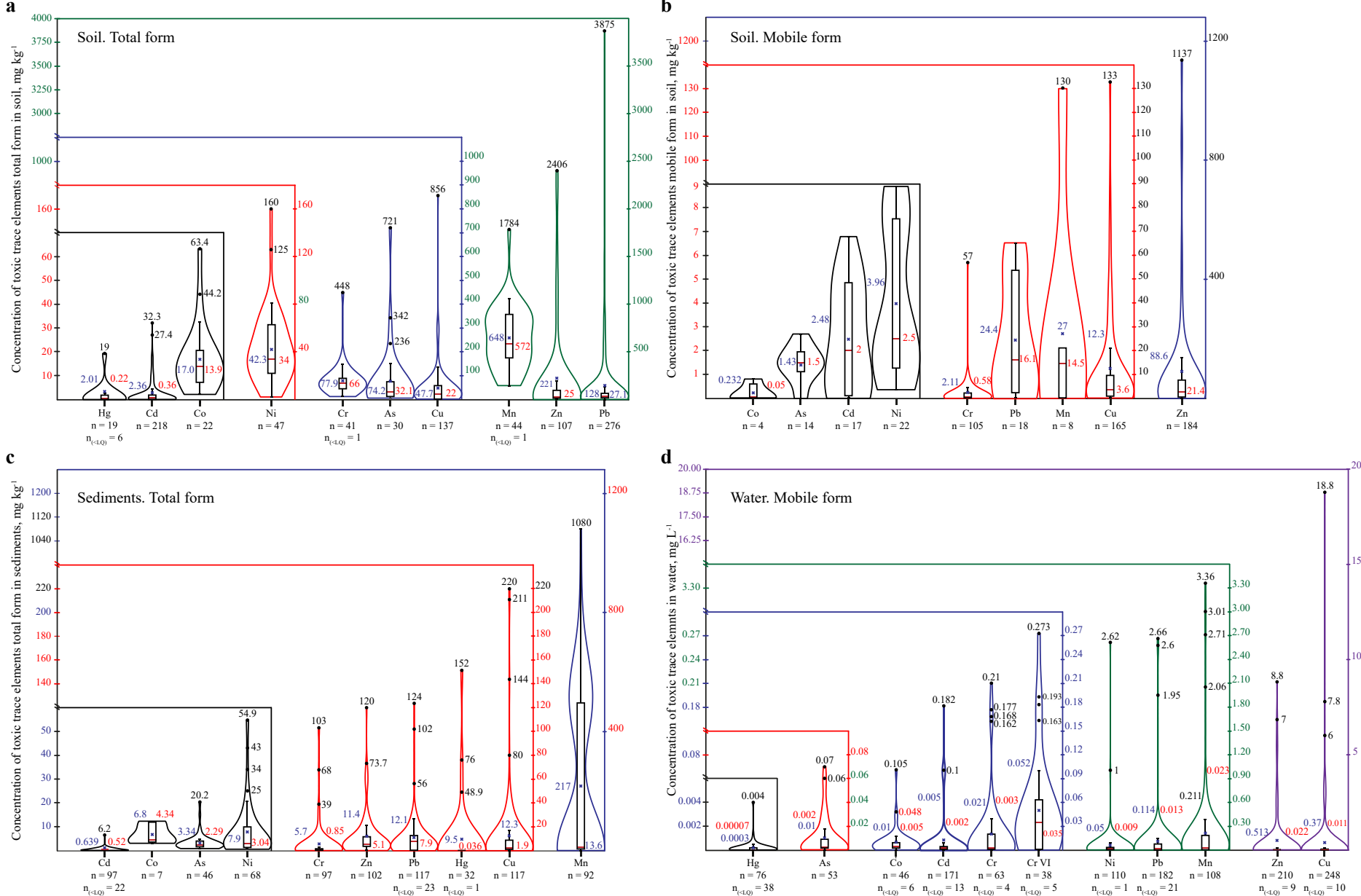

Figure 2. Plots of the heavy metal concentrations in different environmental matters with a box plot for means (blue number), median (red number), and outliers (black numbers) as well as a rotated kernel density plot to illustrate the probability density of the data

a Plots of the concentration of each heavy metals total form in soil.

$b$ Plots of the concentration of the mobile fraction of each heavy metal in soil.

c Plots of the concentration of each heavy metal in sediments

d Plots of the concentration of each heavy metal in surface water 


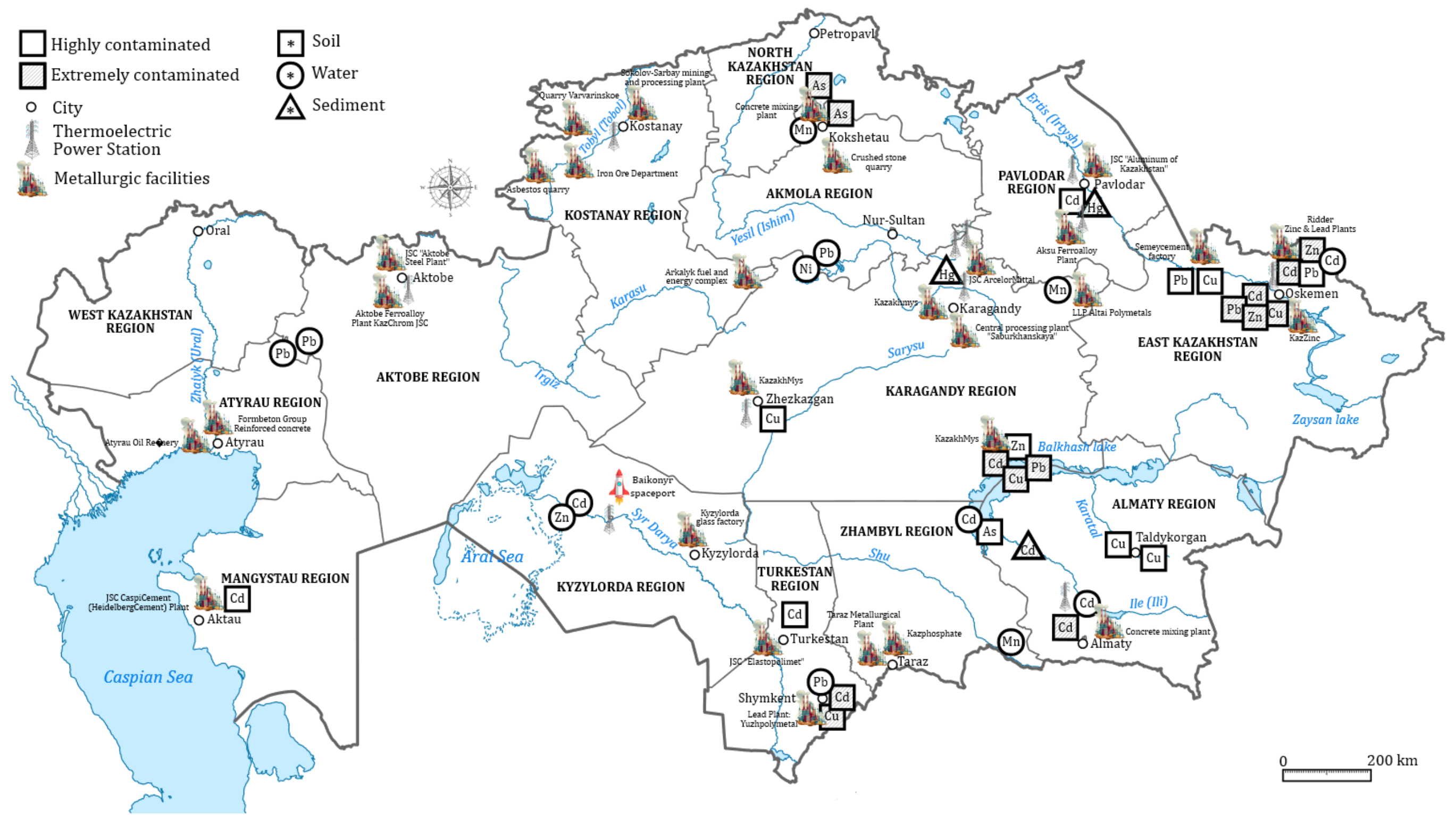

Figure 3. Identified hotspots of the different elements in soil (square), sediments (triangle), and surface water (ring) as well as emitting sources on the territory of the Republic of Kazakhstan 


\section{References}

Abrahams PW, Steigmajer J (2003) Soil Ingestion By Sheep Grazing the Metal Enriched Floodplain Soils of Mid-Wales. Environ Geochem Health 25:17-24. https://doi.org/10.1023/A:1021217402950

Akhmetsadykova S (2012) Impact of pollution on the quality of camel milk in Kazakhstan. Thesis, Montpellier SupAgro

Amankosova A (2013) Monitoring of the ecological situation of the North-Western industrial zone of Aktobe. Eurasian J Ecol 38:21-23

Amirgaliev N (2013) Assessment of anthropogenic pollution of the River Elek. J Questions of Geography and Geoecology 11-18

Amirgaliev N, Ismukhanova L (2013) Water quality of River Elek. J Questions of Geography and Geoecology 1:19-23

Amirgaliev N, Ismukhanova L (2014) Hydrological conditions of the Kapshagai Reservoir as a part of the Altyn-Emel state National Natural Park. In: Success of the formation and functioning of the network of specially protected natural territories and biodiversity studies. Kostanay, Kazakhstan, pp 202-206

Amirgaliev N, Ismukhanova L (2015) Dynamics of heavy metals in water of the Kapshagai Reservoir of lli River. Minsk, Belarus, pp 48-50

Amirgaliev N, Ismukhanova L, Bektursunov K (2017) Comprehensive assessment of water quality in Kapshagai Reservoir of the Ili River. Bull Karaganda State Univ, series constructions and architecture 17:109-113

Anzelm K (2012) Observations of the presence of heavy metals in the arable horizon of irrigated sierozems of Southern Kazakhstan. 3:142-145

Arystambekova D, Thevs N, Tursumbayeva M (2019) Assessment of the hydroecological state of the Syrdarya delta. Central Asian Journal of Water Research (CAJWR) 5:29 41. https://doi.org/10.29258/CAJWR/2019-R1.v5-1/29-41.eng

Baimakova E (2002) Evaluation of influence of tailing dumps of the Balkhash concentrating mill on the environment. 15:48-57

Barinova S, Krupa E, Kadyrova U (2017) Spatial dynamics of species richness of phytoplankton of Lake Balkhash in the gradient of abiotic factors. Transylvanian Review of Systematical and Ecological Research 19:1-18. https://doi.org/10.1515/trser-2017$\underline{0009}$

Bazhieva A, Tursunov E (2011) Water quality and mass of pollutants entering in rivers of South and Southwest of Kazakhstan. 4:114-121

Biyasheva Z (2010) Prolonged contamination of heavy metals and radionuclides of the territory adjacent to mining treatment plant in Tekeli town. 29:60-65

Boluspaeva L, Panin M (2012) Heavy metals in the soils of the Ust-Kamenogorsk city, Republic of Kazakhstan. 19:803-810

Bosch K, Erdinger L, Ingel F, et al (2007) Evaluation of the toxicological properties of ground- and surface-water samples from the Aral Sea Basin. Science of The Total Environment 374:43-50. https://doi.org/10.1016/..scitotenv.2006.11.048

Burlibayev Mz, Amirgaliev N, Myrtasin Ez, et al (2012) Dynamics of the hydrometric regime of toxicological parameters and their transformations in the transboundary river Ertis. 50:9-20

Burlibayev Mz, Amirgaliev N, Myrtasin Ez, et al (2013a) Current conditions of the hydrometric regime and toxicological parameters of transboundary rivers of the Balkhash-Altai Basin. 1:117-128

Burlibayev MZ, Amirgaliev NA, Shenberger IW, Perevalov AC, Burlibayeva DM (2013b) Contemporary assessment of hydrochemical andtoxicological parameters of the crossborder inflow of river Syr Darya and their transformation pattern on the territory of Kazakhstan. 3:141-160

Burlibayev Mz, Amirgaliev N, Myrtasin Ez, et al (2013c) Current hydrometric and toxicological problems of the transboundary rivers of the Zhaiyk (Ural) basin and the transformations of their parameters. 2:76-107

Brunet R (2001) Hauts lieux et mauvais lieux du Kazakhstan. L'Espace Géographique 30:37-51. https://doi.org/10.3917/eg.301.0037

CCME (2008) Protocol for the Derivation of Canadian Sediment Quality Guidelines for the Protection of Aquatic Life. Canadian Council of Ministers of the Environment

Danieli PP, Serrani F, Primi R, et al (2012) Cadmium, Lead, and Chromium in Large Game: A Local-Scale Exposure Assessment for Hunters Consuming Meat and Liver of Wild Boar. Arch Environ Contam Toxicol 63:612-627. https://doi.org/10.1007/s00244012-9791-2

de Mora S, Sheikholeslami MR, Wyse E, et al (2004) An assessment of metal contamination in coastal sediments of the Caspian Sea. Marine Pollution Bulletin 48:61-77. https://doi.org/10.1016/S0025-326X(03)00285-6

Deng M, Zhu Y, Shao K, et al (2020) Metals source apportionment in farmland soil and the prediction of metal transfer in the soil-rice-human chain. J Environ Manage 260:110092. https://doi.org/10.1016/j.jenvman.2020.110092

Diacono E, Faye B, Meldebekova A, Konuspayeva G (2008) Plant, Water and Milk Pollution in Kazakhstan. In: Faye B, Sinyavskiy $Y$ (eds). Springer Netherlands, Dordrecht, pp 107-116

DTTL (2019) Deloitte Touche Tohmatsu Limited. Business Outlook in Kazakhstan. Deloitte CIS Research Centre, ed Deloitte Touche Tohmatsu Ltd.

Dumat C, Pierart A, Shahid M, Khalid S (2019) Pollutants in urban agriculture: sources, health risk assessment and sustainable management. In: Sanchez-Hernandez JC (ed) Bioremediation of Agricultural Soils. CRC press Taylor \& Francis Group, p 290

FAO (2017) Socio-economic context and role of agriculture in Kazakhstan. Country Fact Sheet on Food and Agriculture Policy Trends

GMS (2019) Information bulletin of the Ministry of Ecology, Geology and Natural Resources of RSE "Kazhydromed". On the state of the environment of the Republic of Kazakhstan for 2019

Inelova Z, Nesterova S, Yerubayeva G, et al (2018) Heavy metal accumulation in plants of Atyrau region. Pak J Bot 50:2259-2263

Ismukhanova L, Amirgaliev N, Bektursunov K, Kulbekova R (2016) Spatial-temporal dynamics of heavy metals in water of the Kapshagai reservoir and the River Ili. Jerusalem, Israel, pp 242-246

Janaleyeva K, Zhanguzhin A, Mazhitova G, et al (2017) Features of geochemical conditions of Esil River Geosystems. 3:170-181

Jurjanz S, Feidt C, Pérez-Prieto LA, et al (2012) Soil intake of lactating dairy cows in intensive strip grazing systems. Animal 6:1350-1359. https://doi.org/10.1017/S1751731111002734
Jurjanz S, Germain K, Dziurla MA, et al (2014) Use of acid-insoluble ash and n-alkanes as markers of soil and plant ingestion by chickens. Anim Feed Sci Technol 188:92101. https://doi.org/10.1016/i.anifeedsci.2013.11.004

Kacholi DS, Sahu M (2018) Levels and Health Risk Assessment of Heavy Metals in Soil, Water, and Vegetables of Dar es Salaam, Tanzania. J Chem 2018:9 https://doi.org/10.1155/2018/1402674

Kaliaskarova Z, Aliyeva Z, Ikanova A, Negim E (2019) Soil pollution with heavy metals on the land of the Karasai landfill of municipal solid waste in Almaty city. News of the Academy of Science of the Republic of Kazakhstan, series Geology and Technical Sci 6:256-267

Kanibolotskaya Y, Listkov W, Shmidt N (2019) Heavy metals in soil and plants (Agropyron pectiniforme Roem. Et Schult.) of the Pavlodar region (Kazakhstan). In: IOP Conference Series: Earth and Environmental Science. IOP Publishing, pp 1-5

Kazakh soil regulation (2004) Joint order of the Ministry of Health of the Republic of Kazakhstan dated January 30, 2004 No. 99 and the Ministry of Environmental Protection of the Republic of Kazakhstan dated January 27, 2004, No. 21. Soil uses in the Republic of Kazakhstan

Kazakh standard for environmental safety (2015) Approval of hygienic standards for environmental safety (soil). Order of the Minister of National Economy of the Republic of Kazakhstan dated June 25, 2015 No. 452. Registered with the Ministry of Justice of the Republic of Kazakhstan on July 24, 2015 No. 11755

Kazakh water guidelines (2015) Sanitary and epidemiological requirements for wate sources, places for water intake for household and drinking purposes, drinking wate supply and places for cultural and domestic water use and the safety of water bodies. No. 209, SanPiN April 22, 2015, Republic of Kazakhstan

Kenzhetayev GZ, Syrlybekkyzy S, Zhidebayeva A (2018) Ecological assessment of soils near the cement factory Caspian Cement on the chalk deposits Shetpe South. Eurasian J Ecol 57:32-44

Khanturina G, Seytkasymova Gz, Rusyaev M, et al (2015) Assessment of air pollution in the village of Aiteke-bi of the Aral region of Kazakhstan. Modern High Technology $1: 103-104$

Kin NO (2008) Plant communities in the zone of gas field development and heavy meta accumulation by them. Russ J Ecol 39:254-260. https://doi.org/10.1134/S1067413608040048

Kirshibaev E, Sarsenbaev B, Baiseiytova G, et al (2012) Distribution of heavy metals on bodies of sunflower grown up in the conditions of technogenic pollution of soils. 55:6872

Korolev A, Boev V (2017) Heavy metals in soils and vegetables in the zone of influence of the cement plant in Semey city (Republic of Kazakhstan). 27:74-79

Krupa E, Barinova S, N.A. A, et al (2017) Statistical Approach to Estimate the Anthropogenic Sources of Potentially Toxic Elements on the Shardara Reservoir (Kazakhstan). MOJ Ecol Environ Sci 2:1-8. https://doi.org/10.15406/mojes.2017.02.00012

Krupa EG, Romanova SM, Imentai AK (2016) Hydrochemical and toxicologica characteristics of state national nature park "Kolsay kolderi" lakes (Kungei Alatau, South-Eastern Kazakhstan). Nature Conservation Research 1:2-10

Krupa EG, Stuge TS, Lopareva TYa, Shaukharbaeva DS (2008) Distribution of planktonic crustaceans in Lake Balkhash in relation to environmental factors. Inland Water Biol 1:150-157. https://doi.org/10.1134/S1995082908020077

Ma L, Abuduwaili J, Smanov Z, et al (2019) Spatial and Vertical Variations and Heavy Metal Enrichments in Irrigated Soils of the Syr Darya River Watershed, Aral Sea Basin, Kazakhstan. International Journal of Environmental Research and Public Health 16:4398-4414. https://doi.org/10.3390/ijerph16224398

Mahaev Az (2016) The content of heavy metals in the soil of Irgiz village, Aktobe region in the cold period of 2015. 51:62-67

Matveyeva I, Ponomarenko O, Soltangaziyev N, et al (2019) Heavy metals in soil of Almaty region (Kazakhstan). Chem J Kazakhstan 66:62-68

Moore MJ, Mitrofanov IV, Valentini SS, et al (2003) Cytochrome P4501A expression chemical contaminants and histopathology in roach, goby and sturgeon and chemica contaminants in sediments from the Caspian Sea, Lake Balkhash and the lly Rive Delta, Kazakhstan. Mar Pollut Bull 46:107-119. https://doi.org/10.1016/S0025326X(02)00325-9

Mustafaev Z, Ivanova N, Abdyvalieva K (2017a) Geo-ecological evaluation of transformation of concentration of pollutants in the lows of Syr Darya River. Bull KyrgyzRussian Slavic Univ 17:90-95

Mustafaev Z, Ivanova N, Abdyvalieva K (2017b) Geo-ecological evaluation of hydroogorlanshafts in the lows of Syr Darya River in the conditions of law. Bull KyrgyzRussian Slavic Univ 17:96-102

Mynbaeva B (2012) Analysis of natural and anthropogenic factors of environmental pollution in Almaty. Bull Altai State Agrarian Univ 88:52-56

Mynbaeva B, Makeeva A (2011) Estimation of soil pollution by heavy metals in Almaty city using Chemical and mathematical methods. Fundamental Research 10:131-136 Mynbaeva B, Medvedeva A (2011) The suppression of biochemical activity of contaminated urban soils. News of Altai State Univ 3:23-25

Mynbaeva B, Panin M, Esimov B (2012) Establishment of Almaty's soil toxicity through the change in composition of micro fauna. News Tula State Univ, series Biol 1:284 292

Nesterova S, Inelova Z, Li T, Korotkov V (2013) A variety of Artemisia (genus Artemisia L.) Ile-Balkhash region. Experimental Biol 58:10-13

Nurkuat Z, Kerimkulova A, Temirbaeva K (2015) The study of ecological status of surface waters in Almaty. Bull Kaz Nat Univ, series Ecol 43:101-105

Ogar N, Leonova Y (2009) Accumulation of heavy metals by vegetation and soil in the influence zone of enterprises of the east industrial area of Pavlodar. Experimenta Biology 41:20-25

Ozgeldinova ZhO, Janaleyeva K, David L, et al (2017) Estimating the potentia sustainability of geosystems in conditions of anthropogenic impacts (a case study of Sarysu basin, Kazakhstan). Appl Ecol Env Res 15:1733-1744. https://doi.org/10.15666/aeer/1504 17331744

Panin M, Geldymamedova E (2006) Ecological-geochemical characteristic of soils of Pavlodar (Kazakhstan Republic). Vestn Tomsk Gos Univ 171-177

Pascaud G, Leveque T, Soubrand M, et al (2014) Environmental and health risk assessment of $\mathrm{Pb}, \mathrm{Zn}, \mathrm{As}$ and $\mathrm{Sb}$ in soccer field soils and sediments from mine tailings: solid speciation and bioaccessibility. Environ Sci Pollut Res 21:4254-4264. https://doi.org/10.1007/s11356-013-2297-2 
Russian soil regulation (2006) Maximum permissible concentrations (MPC) of chemicals in the soil. approved by the Chief State Sanitary Doctor of the Russian Federation. Hygienic standards GN 2.1.7.2042-06, Moscow (Russia)

Rzymski P, Klimaszyk P, Niedzielski P, et al (2019) Pollution with trace elements and rare-earth metals in the lower course of Syr Darya River and Small Aral Sea, Kazakhstan. Chemosphere

https://doi.org/10.1016/i.chemosphere.2019.06.036

Safirova E (2019) The mineral industry of Kazakhstan. In: 2015 Minerals Yearbook [Advanced release]. US Department of the Interior \& US Geological Survey, p 24.124.16

Sakiev K, Ibraeva L, Khanturin G (2016) Feature contamination of drinking water, the Yesil. Bull Kyrgyz State Med Academy 16:15-17

Salbu B, Burkitbaev M, Strømman G, et al (2013) Environmental impact assessment of radionuclides and trace elements at the Kurday $\mathrm{U}$ mining site, Kazakhstan. J Environ Radioact 123:14-27. https://doi.org/10.1016/j.jenvrad.2012.05.001

Seytkasymova Gz (2015) Ecological and hygienic assessment of surface water in populated points of Akmola region. Occupational hygiene and medical ecology 4:7882

Shalakhmetova TM, Sutuyeva LR, Mamilov NS, et al (2018) Biotesting of surface water and bottom sediments from the lle River and the southwestern part of the Balkash Lake. Eurasian J Ecol 57:20-30

Sharipova O (2015) Distribution of Heavy Metals in Bottom Sediments of Lake Balkhash Depending on Natural and Anthropogenic Factors. Tomsk State Univ J 390:225-230

Shepelev M (2017) Ecology of soils. Teaching-methodical manual for students of specialty 5B060800 - Ecology. Kostanay, Kazakhstan

Shimshikov B, Izbasarova A (2014) Hydrochemical and toxicological characteristics of the state of the Ural River within the West Kazakhstan region. KazNU Bulletin Ecology series 2:163-167

Sibirkina A (2011) The content of heavy metals in the sand of the pine born of the Semipalatinsk part of the Irtysh river of the Republic of Kazakhstan. Bull Voronezh State Univ, series Chem Biol Pharm 2:46-52

Slivinski G, Krupa E (2013) Contemporary stat Tengiz-Korgalzhyn Lakes by hydrochemical and toxicological indicators. KazNU Bulletin Ecology series 37:74-81

Slivinsky G, Krupa E, Akberdina GZ (2009) Characterization of the Nura river basin in the zone of influence of the Temirtau-Karaganda industrial complex according to hydrochemical and toxicological indicators. Bull Kazakh Natl Univ Ecol Ser 3:82-90

Tattibayeva D, Nebot C, Miranda JM, et al (2016) A study on toxic and essential elements in rice from the Republic of Kazakhstan: comparing the level of contamination in rice from the European Community. Environ Geochem Health 38:85-98. https://doi.org/10.1007/s10653-015-9687-y

Tazitdinova R, Beisenova R, Grigoryev A, Issayenko O (2019) Contamination of soil with heavy metals in industrial districts of Kokshetau. Sci Bul Univ Karaganda, series Biol Med Geogr 94:93-98

Tilekova ZT, Oshakbayev MT, Yerubayeva GK (2015) Assessment of norms of admissible impact on water objects of trans-Balkhash area. Int J Chem Sci 13:14951510

Ullrich SM, llyushchenko MA, Kamberov IM, Tanton TW (2007) Mercury contamination in the vicinity of a derelict chlor-alkali plant. Part I: Sediment and water contamination of Lake Balkyldak and the River Irtysh. Sci Total Environ 381:1-16. https://doi.org/10.1016/j.scitotenv.2007.02.033

WHO (2019) FEED cities project: The food environment in cities in Eastern Europe and Central Asia - Kazakhstan. World Health Organization, Copenhagen, Denmark

Woszczyk M, Spychalski W, Boluspaeva L (2018) Trace metal (Cd, Cu, Pb, Zn) fractionation in urban-industrial soils of Ust-Kamenogorsk (Oskemen), Kazakhstanimplications for the assessment of environmental quality. Environ Monit Assess 190:362. https://doi.org/10.1007/s10661-018-6733-0

Yanygina LV, Evseeva AA (2019) Caddisfly Assemblages in Metal Contaminated Rivers of the Tikhaya Basin, East Kazakhstan. Bull Environ Contam Toxicol 102:316-322. https://doi.org/10.1007/s00128-019-02561-w

Zhang W, Ma L, Abuduwaili J, et al (2020) Distribution Characteristics and Assessment of Heavy Metals in the Surface Water of the Syr Darya River, Kazakhstan. Pol J Environ Stud 29:979-988. https://doi.org/10.15244/pjoes/104357

\section{Acknowledgements}

The authors warmly thank Thomas Schulze (Chelmsford, UK) for English proofreading.

\section{Declarations}

In absence of involved human or animals, an ethical approval or a consent to participate is not applicable for this literature synthesis. A consent for publication is also not relevant for the same reasons.

Author contributions to the present paper are like follows: A Akindykova and A Baubekova carried out the data collection, A Mamirova and S Jurjanz processed the collected data, results were interpreted by S Jurjanz and C Dumat and finally the text of the present manuscript was written by all five authors together.

\section{Conflict of interest and Funding}

The authors declare that they have no conflict of interest and this work has not be founded by any private or governmental establishment.

\section{Availability of data and materials}

We declare that all data used and analyzed in the current study was extracted from the cited literature and the built dataset is fully available from the corresponding author on reasonable request. 